\title{
ANALISIS PENGARUH TANAMAN VETIVER TERHADAP STABILITAS LERENG
}

\author{
Putri Kurniawati $^{1 \otimes}$, Sri Wulandari ${ }^{2}$ \\ ${ }^{1,2}$ Universitas Gunadarma, Program Studi Teknik Sipil, Jl. Margonda Raya No. 100, 16424

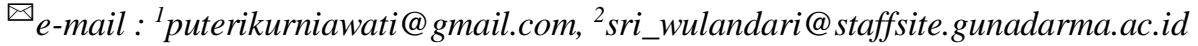

\begin{abstract}
This research analyzed the influence of vetiver strengthening on slope stability. The research do in prototype media, where the slope was planned $80^{\circ}$. Before planting vetiver, firstly original soil is tested by index and engineering properties test. Based on the test, we can conclude that the soil use is silty clay with the value of $q_{u}$ and cohesion of prototype with 3 vetiver are $0,322 \mathrm{~kg} / \mathrm{cm}^{2}$ and $0,085 \mathrm{~kg} / \mathrm{cm}^{2}$. In prototype with 6 vetiver, the value of $q_{u}$ and cohesion are $0,329 \mathrm{~kg} / \mathrm{cm}^{2}$ and $0,025 \mathrm{~kg} / \mathrm{cm}^{2}$. Vetiver planted and tested by direct shear and unconfined compression test at planting time 4 - 7 and 16 weeks. At 16 week, the value of $q_{u}$ and cohesion of prototype with 3 vetiver are $0,714 \mathrm{~kg} / \mathrm{cm}^{2}$ and 0,306 $\mathrm{kg} / \mathrm{cm}^{2}$. In prototype with 6 vetiver, the value of $q_{u}$ and cohesion are $0,782 \mathrm{~kg} / \mathrm{cm}^{2}$ and $0,325 \mathrm{~kg} / \mathrm{cm}^{2}$. The test result parameters are used as inputs to GeoStudio. Based on the program, in prototype with 3 vetiver, the safety factor increase from 0,516 to 1,519, and in prototype with 6 vetiver the safety factor increase from 0,201 to 1,545. So, it can be concluded that vetiver can improve slope stability.
\end{abstract}

Keywords: Vetiver, Cohesion, Slope Stability, Safety Factor

\begin{abstract}
Abstrak
Penelitian ini menganalisis pengaruh perkuatan vetiver terhadap stabilitas lereng. Penelitian dilakukan dengan media prototype, dimana kemiringan lereng direncanakan $80^{\circ}$. Sebelum dilakukan penanaman vetiver, terlebih dahulu dilakukan pengujian karakteristik tanah asli. Berdasarkan pengujian diperoleh data bahwa tanah yang digunakan merupakan tanah lempung kelanauan dengan nilai $q_{u}$ dan kohesi prototype 3 tunas vetiver sebesar $0,322 \mathrm{~kg} / \mathrm{cm}^{2}$ dan $0,085 \mathrm{~kg} / \mathrm{cm}^{2} . P a d a$ prototype 6 tunas vetiver nilai $q_{u}$ dan kohesi sebesar $0,329 \mathrm{~kg} / \mathrm{cm}^{2}$ dan $0,025 \mathrm{~kg} / \mathrm{cm}^{2}$. Selanjutnya dilakukan penanaman vetiver dan diuji nilai kuat tekan dan kuat geser tanah dengan perkuatan pada waktu tanam 4 - 7 dan 16 minggu. Pada minggu ke- 16 diperoleh nilai $q_{u}$ dan kohesi prototype 3 tunas vetiver sebesar $0,714 \mathrm{~kg} / \mathrm{cm}^{2}$ dan $0,306 \mathrm{~kg} / \mathrm{cm}^{2}$. Pada prototype 6 tunas vetiver nilai $q_{u}$ dan kohesi $0,782 \mathrm{~kg} / \mathrm{cm}^{2}$ dan $0,325 \mathrm{~kg} / \mathrm{cm}^{2}$. Parameter hasil pengujian tersebut digunakan sebagai input pada program GeoStudio. Berdasarkan program tersebut diperoleh nilai faktor keamanan lereng pada prototype 3 tunas vetiver meningkat dari 0,516 menjadi 1,519, dan pada prototype 6 tunas vetiver faktor keamanan meningkat dari 0,201 menjadi 1,545. Maka, dapat diambil kesimpulan bahwa vetiver dapat meningkatkan kestabilan lereng.
\end{abstract}

Kata kunci: Vetiver, Kohesi, Stabilitas Lereng, Faktor Keamanan

Pendahuluan

Kondisi lereng dengan kemiringan curam dapat mengakibatkan kelongsoran. Kelongsoran merupakan hal yang marak terjadi saat ini, terutama kelongsoran pada lereng jalan yang berbukit. Hal ini tentunya membahayakan pengguna jalan, sehingga diperlukan perkuatan lereng untuk meningkatkan stabilitas lereng.
Saat ini telah banyak upaya yang dapat dilakukan sebagai alternatif perkuatan lereng, salah satunya dengan vegetasi. Truong (2002), menyatakan bahwa vetiver cocok untuk stabilisasi lereng antara lain karena sistem perakaran yang banyak dan menembus sangat dalam kedalam tanah, sistem akar yang tebal dan ekstensif dapat mengikat tanah, vetiver membentuk pagar hidup yang padat apabila ditanam berdekatan, selain itu vetiver juga mampu untuk 
tumbuh kembali setelah mengalami kemarau panjang [1].

Akar vetiver memiliki kekuatan tarik yang bervariasi, yaitu antara 40-180 MPa. Kekuatan tarik rata-rata vetiver sekitar $75 \mathrm{MPa}$ (setara dengan sekitar seperenam baja ringan). Ini menunjukkan bahwa akar vetiver sama kuatnya dengan, atau bahkan lebih kuat dari akar banyak spesies kayu keras, yang telah terbukti positif untuk penguat akar di lereng curam [2].

Selain fakta di atas, akar tanaman vetiver diketahui dapat menembus lapisan tanah yang sangat keras sampai dengan ketebalan $15 \mathrm{~cm}$. Ujung akar vetiver mampu masuk menembus lapisan tanah dan berperan menjadi semacam jangkar yang kuat pada lereng-lereng keras dan berbatu. Prinsip kerja akar ini seperti struktur kolom yang ditancapkan ke dalam tanah dengan fungsi ganda yaitu dapat menahan menahan partikel-partikel tanah dengan akar serabutnya. Kondisi seperti ini dapat mencegah erosi yang disebabkan oleh angin dan air sehingga tanaman vetiver dijuluki sebagai "kolom hidup" [3].

Tanaman vetiver mempunyai manfaat sebagai stabilisasi bioengineering untuk menstabilkan tebing sungai, kanal irigasi, pengendalian erosi sungai dan tanggul pantai, lereng galian dan timbunan pada jalan raya, bukit pasir, erosi pada lahan pertanian yang berlereng [4].

Pada penelitian "Penanganan Erosi Lereng Galian dan Timbunan Jalan dengan Rumput Vetiver" oleh G. Gunawan tahun 2008, diperoleh data bahwa tanaman vetiver dengan media tanam yang diberi pupuk dengan perbandingan 3:1 akan menghasilkan panjang $\pm 40 \mathrm{~cm}$ selama \pm 2 minggu penanaman. Pertumbuhan akar pada waktu 6 minggu mencapai $70 \mathrm{~cm}$.

Firmansyah Ilham (2010) dalam jurnal yang berjudul "Karakteristik Mekanis Perkuatan Lereng Menggunakan Geo-
Root dengan Tanaman Vetiver", melakukan penelitian menggunakan 3 variasi rumput vetiver dengan variasi kedalaman sampel $0-30 \mathrm{~cm}$ dan $30-$ $60 \mathrm{~cm}$. Pengujian sifat fisik dan mekanis tanah dilakukan pada umur tanam vetiver $4,5,6$, dan 7 minggu. Berdasarkan hasil pengujian, tanaman vetiver mampu meningkatkan sifat fisik dan mekanis tanah. Penanaman vetiver memberikan peningkatkan nilai kuat tekan bebas dari $0,107 \mathrm{~kg} / \mathrm{cm}^{2}$ menjadi $0,440 \mathrm{~kg} / \mathrm{cm}^{2}$ pada variasi 9 rumpun dengan kedalaman $0-30 \mathrm{~cm}$ pada minggu ketujuh. Peningkatkan nilai kohesi (c) dari $0,05 \mathrm{~kg} / \mathrm{cm}^{2}$ menjadi $0,34 \mathrm{~kg} / \mathrm{cm}^{2}$, dan nilai sudut geser $(\varphi)$ dari $24^{\circ}$ menjadi $37^{\circ}$ pada variasi 9 rumpun dengan kedalaman $0-30 \mathrm{~cm}$ pada minggu ketujuh [5].

Zulkarnain (2014), dalam jurnal yang berjudul "Analisa Numerik Pengaruh Tanaman Vetiver Terhadap Stabilitas Lereng", dilakukan penelitian dengan menggunakan 2 varian rumpun vetiver. Diperoleh nilai sudut geser tanah asli (ழ) $24^{\circ}$, kohesi (c) $0,05 \mathrm{~kg} / \mathrm{cm}^{2}$, dan kuat tekan bebas $\left(\mathrm{q}_{\mathrm{u}}\right)=0,107 \mathrm{~kg} / \mathrm{cm}^{2}$. Pada variasi 6 tunas diperoleh nilai sudut geser $(\varphi) 34,5^{\circ}$, kohesi (c) 0,31 $\mathrm{kg} / \mathrm{cm}^{2}$, dan kuat tekan bebas ( $\mathrm{q}_{\mathrm{u}}$ ) 0,309 $\mathrm{kg} / \mathrm{cm}^{2}$. Sedangkan pada variasi 9 tunas diperoleh nilai sudut geser $(\varphi) 36^{\circ}$, kohesi (c) $0,32 \mathrm{~kg} / \mathrm{cm}^{2}$, dan kuat tekan bebas $\left(\mathrm{q}_{\mathrm{u}}\right) 0,356 \mathrm{~kg} / \mathrm{cm}^{2}$. Nilai safety factor yang diperoleh pada kondisi tanah asli sebesar 1,369 , pada variasi 6 tunas sebesar 2,187 dan pada variasi 9 tunas sebesar 2,190 [6] .

Berdasarkan penelitian yang telah dilakukan, vetiver memberikan dampak yang baik bagi kekuatan tanah dalam menahan tekanan arah vertical maupun horizontal. Oleh karena itu, pada penelitian ini digunakan vetiver sebagai metode stabilisasi lereng. Pada penelitian ini ditinjau faktor kemiringan lereng. Kemiringan lereng ditinjau pada sudut $80^{\circ}$, sudut kemiringan ini digunakan mengacu pada permasalahan 
keterbatasan lahan yang sering dialami pada proses perencanaan konstruksi jalan. Analisis pengaruh tanaman vetiver terhadap stabilitas lereng dilakukan dengan menggunakan media prototype. Variasi jumlah tunas vetiver yang digunakan yaitu 3 dan 6 rumpun tunas, dengan pengujian kuat tekan dan kuat geser tanah pada kedalaman $0-30$ $\mathrm{cm}$ dan $30-60 \mathrm{~cm}$ pada umur tanam vetiver 4, 5, 6, 7 dan 16 minggu.

\section{Metode Penelitian}

Penelitian analisa pengaruh tanaman vetiver terhadap stabilitas lereng dilakukan pada media prototype. Prototype digunakan sebagai media untuk mensimulasikan kondisi lereng dengan kemiringan $80^{\circ}$ dan ditanami vetiver. Penanaman vetiver dilakukan dengan pola yang telah ditentukan Bina Marga No.11 /S/BNKT/1991 mengenai Spesifikasi Penguatan Tebing yang terdapat pada Gambar 1 [7].

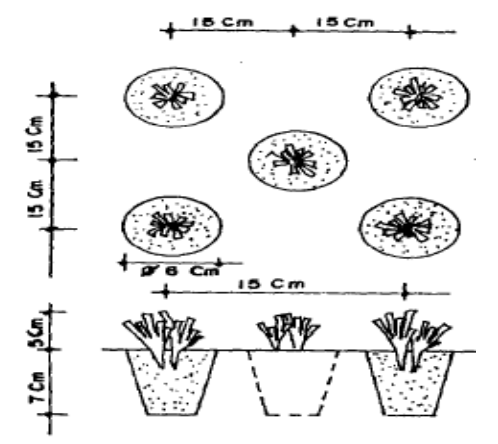

Gambar 1. Jarak dan Posisi Lubang untuk Penanaman Tunas Rumput

Tanaman vetiver disiram sejak awal penanaman, paling sedikit dilakukan selama 3 bulan awal umur tanam vetiver. Penyiraman dilakukan setiap pagi dan sore hari yaitu sebelum jam 9 pagi atau setelah jam 4 sore.

Selama dua minggu pertama setelah vetiver ditanam, penyiraman dilakukan setiap hari. Kemudian, untuk 2 minggu berikutnya tanaman vetiver disiram 2 hari sekali selama. Pada minggu ke-5 hingga usia tanaman 3 bulan, tanaman disiram 2 kali seminggu. Setelah umur 3 bulan, tanaman vetiver diharapkan sudah tumbuh kuat sehingga tidak perlu lagi dilakukan penyiraman [8].

Sebelum dilakukan penanaman vetiver, terlebih dahulu dilakukan pengujian karakteristik fisik (index properties) dan karakteristik mekanis (engineering properties) tanah asli. Hal ini bertujuan untuk mengetahui kondisi tanah dalam keadaan asli sebelum dilakukan perkuatan dengan vetiver.

Penanaman vetiver dilakukan selama 4 bulan, dimana pada minggu ke-4, 5, 6, 7 dan 16 dilakukan pengambilan sampel uji untuk mengetahui pengaruh penanaman vetiver terhadap karakteristik mekanis tanah. Parameter hasil uji kemudian digunakan sebagai input dari analisis menggunakan program GeoStudio. Dari hasil program tersebut dapat diketahui nilai faktor keamanan lereng dan pola bidang longsor pada lereng sehingga dapat diambil kesimpulan pengaruh tanaman vetiver terhadap stabilitas lereng. Alur penelitian pengaruh tanaman vetiver terhadap stabilitas lereng dengan kemiringan $80^{\circ}$ terdapat pada Gambar 2. 


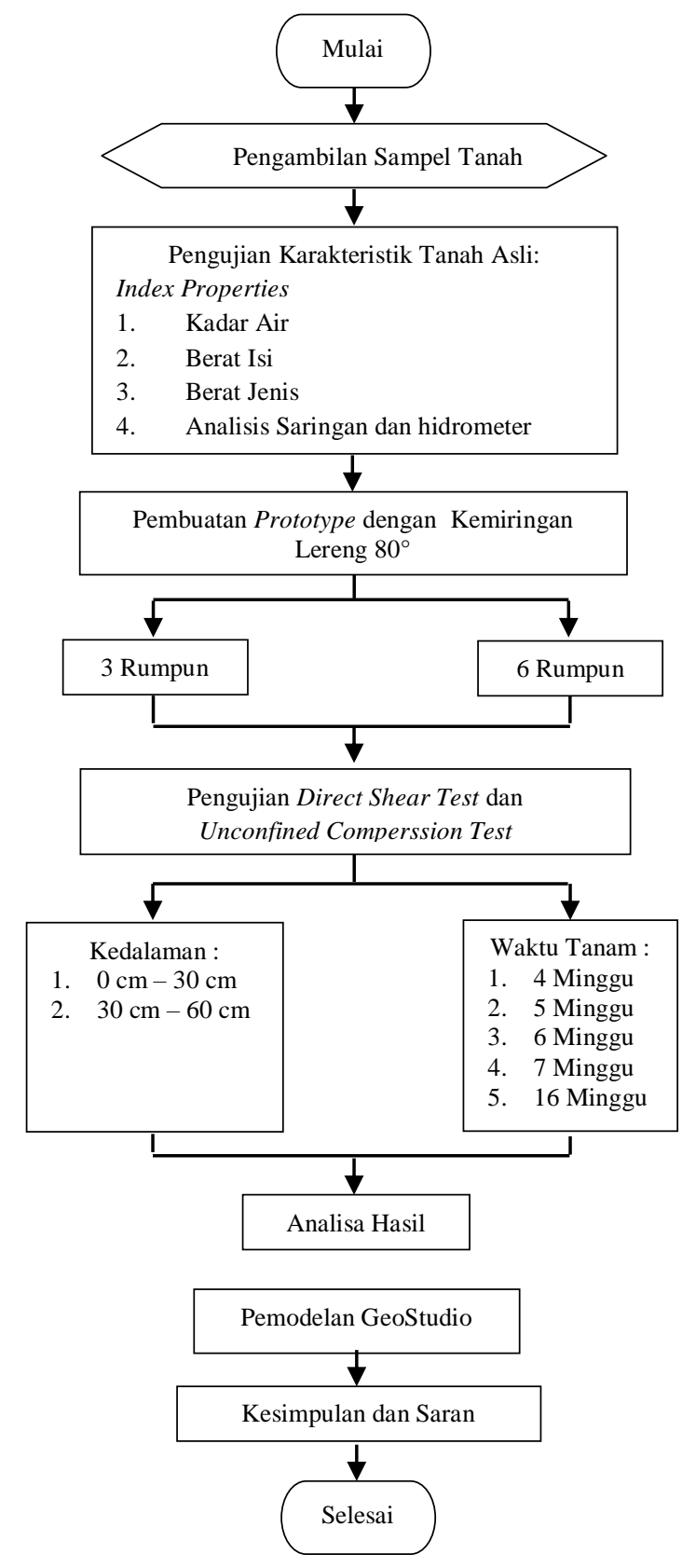

Gambar 2. Alur Penelitian Analisa Pengaruh Tanaman Vetiver Terhadap Stabilitas Lereng

\section{Hasil dan Pembahasan}

Pengujian index dan engineering properties tanah dilakukan pada kondisi tanah asli. Sementara itu, tanah dengan perkuatan vetiver hanya dilakukan pengujian engineering properties. Parameter hasil pengujian selanjutnya digunakan sebagai input pada program GeoStudio untuk dapat menganalisis stabilitas lereng yang dapat diketahui melalui nilai faktor keamanan.

\section{Karakteristik Tanah Asli}

Pengujian indeks properties dan engineering properties dilakukan sebagai langkah awal agar dapat diketahui klasifikasi tanah asli yang akan digunakan pada penelitian. Index properties test yang dilakukan pada penelitian ini meliputi uji kadar air, uji berat jenis $\left(\mathrm{G}_{\mathrm{s}}\right)$, analisis gradasi butiran dan hydrometer, serta batas-batas atterberg. Berdasarkan pengujian diperoleh data sebagai berikut:

a. Kadar air

Kadar air tanah asli yang diperoleh berdasarkan pengujian kadar air yaitu sebesar $50,761 \%$.

b. Berat jenis $\left(\mathrm{G}_{\mathrm{s}}\right)$

Berdasarkan pengujian yang telah dilakukan, diperoleh nilai berat jenis $\left(\mathrm{G}_{\mathrm{s}}\right)$ tanah asli sebesar 2,723. Berdasarkan nilai tersebut, tanah dapat tergolong dalam jenis tanah lempung tak organik.

c. Analisis saringan dan hydrometer

Gambar 2 merupakan grafik gradasi butiran tanah yang diperoleh dari hasil uji analisis saringan dan hydrometer. Klasifikasi The American Association of State Highway and Transportation Official (AASHTO) menjelaskan bahwa jika lebih dari $35 \%$ tanah lolos saringan No. 200, maka tanah termasuk berbutir halus (lanau-lempung). Berdasarkan Gambar 3 diperoleh 81,173\% tanah lolos saringan No. 200.

Pada Gambar 3, tanah dikategorikan ke dalam lima jenis yaitu clay, silt, fine sanf, coarse sand, dan gravel dengan nilai persentase masing-masing terdapat pada Tabel 1 sebagai berikut.

Tabel 1. Hasil Analisis Gradasi Butiran

\begin{tabular}{|c|c|c|}
\hline $\begin{array}{c}\text { Jenis } \\
\text { Tanah }\end{array}$ & Ukuran Partikel & $\begin{array}{c}\text { Persentase } \\
(\%)\end{array}$ \\
\hline Gravel & $>2 \mathrm{~mm}$ & 0,000 \\
\hline $\begin{array}{c}\text { Coarse } \\
\text { sand }\end{array}$ & $2 \mathrm{~mm}-0,420 \mathrm{~mm}$ & 2,756 \\
\hline $\begin{array}{l}\text { Fine } \\
\text { sand }\end{array}$ & $0,420 \mathrm{~mm}-0,074 \mathrm{~mm}$ & 16,072 \\
\hline Silt & $0,074 \mathrm{~mm}-0,002 \mathrm{~mm}$ & 38,138 \\
\hline Clay & $0,002 \mathrm{~mm}$ & 43,035 \\
\hline
\end{tabular}




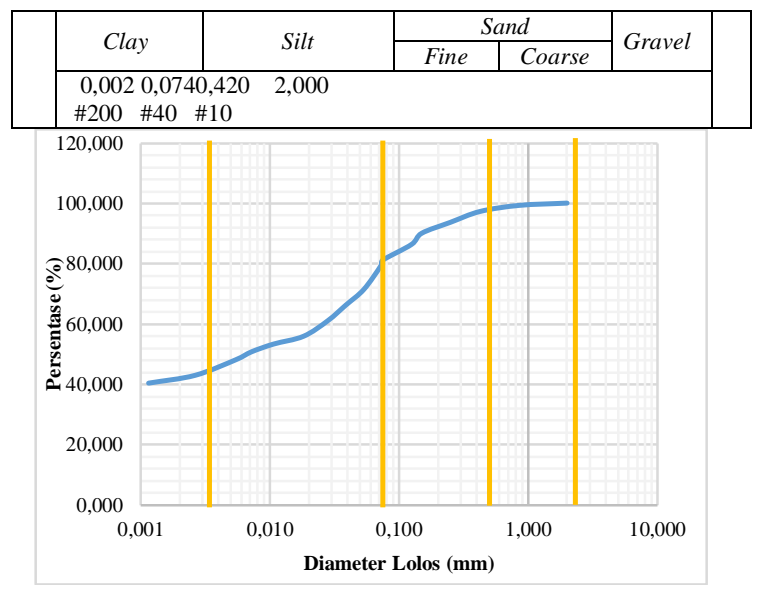

Gambar 3. Grafik Analisis Saringan dan Hydrometer

d. Batas-batas Atterberg

Batas-batas atterberg terdiri dari tiga bagian, yaitu batas susut (Shrinkage Limit, SL), batas plastis (Plastic Limit, PL), dan batas cair (Liquid Limit, LL). Berdasarkan hasil pengujian diperoleh nilai batas susut (Shrinkage Limit, SL) sebesar $17,870 \%$ dan nilai batas plastis (Plastic Limit, PL) sebesar 38,335\%. Nilai batas cair (Liquid Limit, LL) merupakan nilai kadar air pada ketukan ke-25. Nilai LL dapat diperoleh dengan bantuan grafik antara kadar air dan jumlah ketukan. Grafik hubungan antara kadar air tanah dan jumlah ketukan dapat dilihat pada Gambar 4.

Berdasarkan Gambar 4, diperoleh nilai batas cair (LL) adalah 62,479\%. Berdasarkan nilai LL tersebut, maka tanah dapat dikategorikan memiliki plastisitas tinggi. Hal ini dikarenakan nilai $\mathrm{LL}>50 \%$.

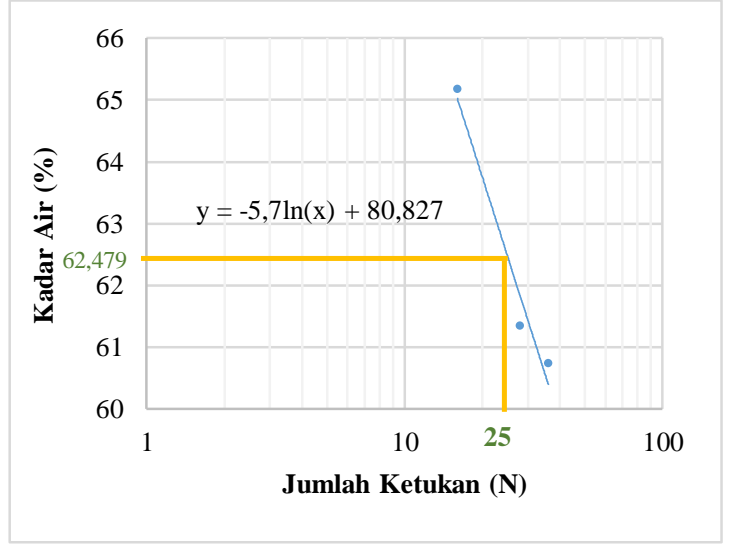

Gambar 4. Hubungan Antara Kadar Air dan Jumlah Ketukan

Jenis tanah dapat juga ditentukan dari nilai LL dan PI dengan menggunakan diagram plastisitas. PI diperoleh dari selisih antara nilai liquid limit (LL) dan nilai plastic limit $(\mathrm{PL}) \rightarrow \mathrm{PI}=\mathrm{LL}-\mathrm{PL}$. Maka dapat diperoleh nilai PI = $62,479 \%-38,335 \%=24,145 \%$.

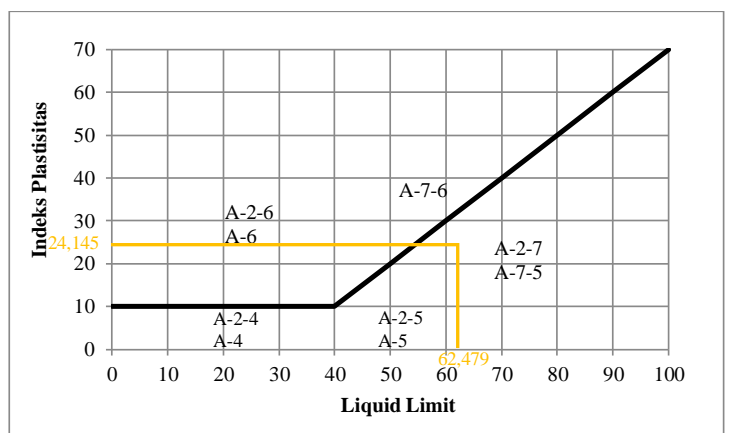

Gambar 5. Grafik plastisitas untuk klasifikasi tanah AASHTO

Berdasarkan Gambar 5 dengan menghubungkan nilai LL 62,479\% dan nilai PI $24,145 \%$ diperoleh golongan tanah pada A-2-7 atau A-7-5. Berdasarkan klasifikasi AASHTO, A-27 merupakan golongan tanah butir kasar dan A-7-5 merupakan golongan tanah butir halus. Mengacu pada hasil pengujian analisa saringan dan hidometer, $35 \%$ tanah berhasil melewati saringan No. 200 yang berarti tanah tergolong dalam butir halus. Oleh karena itu, tanah dapat digolongkan ke dalam grup A-7-5. 
Selain dengan menggunakan grafik plastisitas pada Gambar 5, klasifikasi tanah berdasarkan AASHTO dapat juga dilakukan dengan menggunakan Tabel 2.

Tabel 2. Klasifikasi Tanah Berdasarkan AASHTO

\begin{tabular}{|c|c|c|c|c|}
\hline \multirow[t]{2}{*}{ Klasifikasi umum } & \multicolumn{4}{|c|}{$\begin{array}{c}\text { Tanah lanau - lempung } \\
\text { (Lebih dari 35\% dari seluruh contoh } \\
\text { tanah lolos ayakan No. 200) }\end{array}$} \\
\hline & A- 4 & A-5 & A- 6 & $\begin{array}{l}\text { A-7-5 } \\
\text { A-7-6 }\end{array}$ \\
\hline $\begin{array}{l}\text { Analisa saringan } \\
\text { (\% lolos) } \\
\text { No. } 10 \\
\text { No. } 40 \\
\text { No. } 200\end{array}$ & $\operatorname{Min} 36$ & $\operatorname{Min} 36$ & $\operatorname{Min} 36$ & Min 36 \\
\hline $\begin{array}{l}\text { Sifat friksi yang lolos } \\
\text { No. } 4 \\
\text { Batas cair }(\mathrm{LL}) \\
\text { Indeks plastisitas }(\mathrm{PI})\end{array}$ & $\begin{array}{l}\text { Maks } \\
40 \\
\text { Maks } \\
10\end{array}$ & $\begin{array}{c}\text { Min } 41 \\
\text { Maks } \\
10\end{array}$ & $\begin{array}{c}\text { Maks } \\
40 \\
\text { Min } 11\end{array}$ & $\begin{array}{c}\text { Maks } \\
41 \\
\text { Min } 11\end{array}$ \\
\hline $\begin{array}{l}\text { Tipe material yang } \\
\text { paling dominan }\end{array}$ & \multicolumn{2}{|c|}{ Tanah berlanau } & \multicolumn{2}{|c|}{ Tanah berlempung } \\
\hline $\begin{array}{l}\text { Penilaian sebagai } \\
\text { bahan tanah dasar }\end{array}$ & \multicolumn{4}{|c|}{ Bisa sampai jelek } \\
\hline
\end{tabular}

Berdasarkan hasil analisis saringan dan hydrometer terdapat $81,173 \%$ tanah lolos saringan No.200, maka tanah dapat diklasifikasikan silt-clay material. Dengan nilai PI $\leq \mathrm{LL}-30$ $(24,145 \% \leq 32,479 \%)$ sehingga tanah termasuk dalam grup A-7-5. Tanah dengan group classification A-7-5 merupakan tanah lempung yang memiliki penilaian variasi sedang sampai buruk (fair to poor) bila digunakan sebagai subgrade.

Berdasarkan hasil engineering propereties test diperoleh nilai kuat tekan bebas tanah asli sebesar 0,322 $\mathrm{kg} / \mathrm{cm}^{2}$ untuk prototype 3 tunas vetiver dan $0,329 \mathrm{~kg} / \mathrm{m}^{2}$ untuk prototype 6 tunas vetiver. Berdasarkan nilai tersebut, tanah dapat dikategorikan berkonsistensi lunak (soft) karena memiliki range nilai kuat tekan bebas antara $0,25 \mathrm{~kg} / \mathrm{cm}^{2}-0,50 \mathrm{~kg} / \mathrm{cm}^{2}$. Sementara itu, dari hasil pengujian geser langsung diperoleh nilai kohesi pada prototype 3 tunas sebesar 0,085 $\mathrm{kg} / \mathrm{cm}^{2}$ dan pada prototype 6 tunas sebesar $0,025 \mathrm{~kg} / \mathrm{cm}^{2}$, dengan range nilai kohesi antara $0-0,125 \mathrm{~kg} / \mathrm{cm}^{2}$ maka tanah dikategorikan memiliki konsistensi sangat lunak (very soft).

Tanah dengan konsistensi sangat lunak (very soft) sampailunak (soft) dapt diartikan tidak memiliki kemampuan yang baik dalam menahan beban (arah vertical maupun horizontal). Oleh karena itu, perlu dilakukan perbaikan tanah untuk dapat meningkatkan konsistensi tanah agar tanah mampu menahan beban dengan baik. Pada penelitian ini metode perbaikan tanah dilakukan dengan cara vegetasi, yaitu dengan menggunakan tanaman vetiver.

\section{Karakteristik Tanah dengan Perkuatan Vetiver}

Pengujian yang dilakukan pada sampel tanah dengan perkuatan vetiver meliputi uji kuat tekan bebas dan uji geser langsung.

a. Kuat tekan bebas

Pengujian kuat tekan bebas dilakukan pada kondisi tanah asli dan dengan perkuatan tanaman vetiver 3 tunas dan 6 tunas. Pada kondisi dengan perkuatan, pengujian dilakukan pada umur tanam tanaman vetiver $4,5,6,7$ dan 16 minggu dengan posisi pengambilan sampel masing-masing pada kedalaman $0-30 \mathrm{~cm}$ dan $30-60 \mathrm{~cm}$. Berdasarkan pengujian kuat tekan bebas diperoleh nilai kuat tekan bebas tanah $\left(\mathrm{q}_{\mathrm{u}}\right)$. Selain nilai kuat tekan bebas $\left(\mathrm{q}_{\mathrm{u}}\right)$, diperoleh nilai kadar air tanah. Hasil pengujian kuat tekan bebas untuk perkuatan 3 tunas dan 6 tunas tanaman vetiver dengan umur tanam 4, 5, 6, 7, dan 16 minggu terdapat pada Tabel 3 sebagai berikut.

Berdasarkan hasil pengujian kuat tekan bebas pada prototype dengan 3 tunas vetiver dipeoleh peningkatan nilai $\mathrm{q}_{\mathrm{u}}$ dari $0,322 \mathrm{~kg} / \mathrm{cm}^{2}$ pada tanah asli menjadi $0,714 \mathrm{~kg} / \mathrm{cm}^{2}$ (kedalaman $0-$ $30 \mathrm{~cm}$ ) dan $0,654 \mathrm{~kg} / \mathrm{cm}^{2}$ (kedalaman $30-60 \mathrm{~cm}$ ) pada kondisi dengan perkuatan vetiver di umur tanam 16 minggu. Pada prototype 6 tunas vetiver nilai $\mathrm{q}_{\mathrm{u}}$ meningkat dari $0,322 \mathrm{~kg} / \mathrm{cm}^{2}$ 
menjadi $0,782 \mathrm{~kg} / \mathrm{cm}^{2}$ (kedalaman $0-$ $30 \mathrm{~cm}$ ) dan $0,763 \mathrm{~kg} / \mathrm{cm}^{2}$ (kedalaman $30-60 \mathrm{~cm}$ ). Berdasarkan data tersebut dapat diambil kesimpulan bahwa jumlah tunas vetiver juga mempengaruhi peningkatan nilai $\mathrm{q}_{\mathrm{u}}$. Nilai $\mathrm{q}_{\mathrm{u}}$ dengan perkuatan 6 tunas vetiver $0,782 \mathrm{~kg} / \mathrm{cm}^{2}$ dan $0,763 \mathrm{~kg} / \mathrm{cm}^{2}$. Nilai tersebut lebih besar dibandingkan nilai $\mathrm{q}_{\mathrm{u}}$ dengan perkuatan 3 tunas vetiver yaitu 0,714 dan 0,654 . Berdasarkan data tersebut, diperoleh range nilai $\mathrm{q}_{\mathrm{u}} 0,500 \mathrm{~kg} / \mathrm{cm}^{2}-1,00$ $\mathrm{kg} / \mathrm{cm}^{2}$. Maka tanah dapat dikategorikan dalam konsistensi teguh (firm). Konsistensi tanah meningkat dari kategori lunak (soft) pada tanah asli, menjadi konsistensi teguh (firm) setelah dilakukan perkuatan tanaman vetiver.

Tabel 3. Hasil Pengujian Kuat Tekan Bebas

\begin{tabular}{|c|c|c|c|c|c|}
\hline \multirow[t]{2}{*}{$\begin{array}{l}\text { Keda- } \\
\text { laman }\end{array}$} & \multirow{2}{*}{$\begin{array}{c}\text { Waktu } \\
\text { Tanam } \\
\text { (Minggu) }\end{array}$} & \multicolumn{2}{|c|}{$\mathrm{q}_{\mathrm{u}}\left(\mathrm{kg} / \mathrm{cm}^{2}\right)$} & \multicolumn{2}{|c|}{ Kadar Air (\%) } \\
\hline & & $\begin{array}{c}3 \\
\text { Tunas }\end{array}$ & $\begin{array}{c}6 \\
\text { Tunas }\end{array}$ & $\begin{array}{c}3 \\
\text { Tunas }\end{array}$ & $\begin{array}{c}6 \\
\text { Tunas }\end{array}$ \\
\hline \multirow{6}{*}{$0-30$} & $\begin{array}{c}0 \\
\text { (Tanah Asli) }\end{array}$ & 0,322 & 0,329 & 59,84 & 59,52 \\
\hline & 4 & 0,409 & 0,596 & 59,09 & 57,89 \\
\hline & 5 & 0,424 & 0,61 & 58,87 & 57,06 \\
\hline & 6 & 0,459 & 0,623 & 58,5 & 56,68 \\
\hline & 7 & 0,464 & 0,624 & 57,96 & 55,97 \\
\hline & 16 & 0,714 & 0,782 & 57,07 & 54,89 \\
\hline \multirow{6}{*}{$30-60$} & $\begin{array}{c}0 \\
\text { (Tanah Asli) }\end{array}$ & 0,322 & 0,329 & 59,84 & 59,52 \\
\hline & 4 & 0,341 & 0,344 & 59,34 & 58,12 \\
\hline & 5 & 0,391 & 0,347 & 59,22 & 57,91 \\
\hline & 6 & 0,429 & 0,469 & 58,98 & 57,38 \\
\hline & 7 & 0,455 & 0,486 & 58,72 & 57,08 \\
\hline & 16 & 0,654 & 0,763 & 58,39 & 56,44 \\
\hline
\end{tabular}

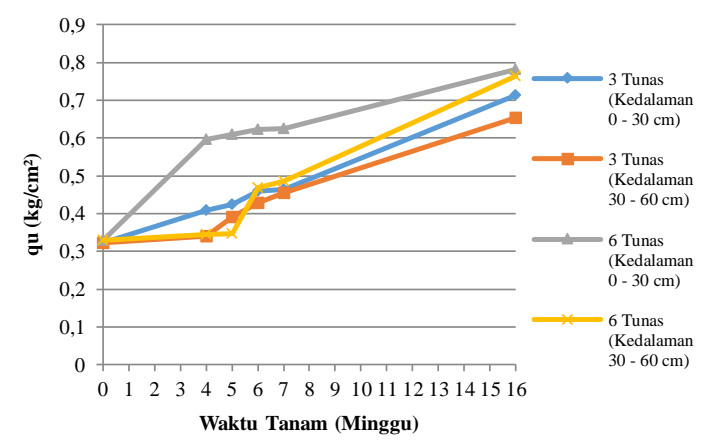

Gambar 6. Grafik Waktu Tanam vs $\mathrm{q}_{\mathrm{u}}$

Pada Gambar 6 dapat dilihat bahwa nilai tekan bebas $\left(\mathrm{q}_{\mathrm{u}}\right)$ meningkat seiring dengan bertambahnya waktu tanam vetiver. Nilai kuat tekan bebas $\left(\mathrm{q}_{\mathrm{u}}\right)$ tanaman vetiver dengan perkuatan 6 tunas tanaman vetiver cendrung lebih besar dibandingkan dengan nilai kuat tekan bebas pada perkuatan 3 tunas vetiver. Akan tetapi nilai kuat tekan bebas 6 tunas tanaman vetiver pada minggu ke 5 di kedalaman $30-60 \mathrm{~cm}$ lebih kecil dari nilai kuat tekan bebas 3 tunas vetiver pada kedalaman $30-60$ $\mathrm{cm}$. Hal ini terjadi dikarenakan pada umur tanam 5 minggu di kedalaman 30 - $60 \mathrm{~cm}$ dengan 6 tunas tanaman vetiver belum terdapat akar tanaman pada sampel uji. Sehingga tidak terdapat peningkatan nilai kuat tekan bebas yang signifikan pada sampel ini.

\section{b. Kuat Geser Langsung}

Pengujian kuat geser langsung dilakukan pada kondisi tanah asli dan dengan perkuatan tanaman vetiver 3 tunas dan 6 tunas. Pada kondisi dengan perkuatan, pengujian dilakukan pada umur tanam tanaman vetiver $4,5,6,7$ dan 16 minggu dengan posisi pengambilan sampel masing-masing pada kedalaman $0-30 \mathrm{~cm}$ dan $30-60$ $\mathrm{cm}$. Berdasarkan pengujian kuat geser langsung diperoleh nilai kohesi (c). Hasil pengujian geser langsung dapat dilihat pada Tabel 4. Secara global trend nilai kohesi terhadap waktu tanam dapat dilihat pada Gambar 7.

Berdasarkan hasil pengujian geser langsung dapat disimpulkan bahwa vetiver dapat meningkatkan nilai kohesi (c). Pada prototype dengan 3 tunas vetiver nilai kohesi meningkat dari $0,085 \mathrm{~kg} / \mathrm{cm}^{2}$ menjadi $0,306 \mathrm{~kg} / \mathrm{cm}^{2}$ (kedalaman $0-30 \mathrm{~cm}$ ) dan 0,304 $\mathrm{kg} / \mathrm{cm}^{2}$ (kedalaman $30-60 \mathrm{~cm}$ ). Pada prototype 6 tunas vetiver nilai kohesi meningkat dari $0,025 \mathrm{~kg} / \mathrm{cm}^{2}$ menjadi $0,325 \mathrm{~kg} / \mathrm{cm}^{2}$ (kedalaman $0-30 \mathrm{~cm}$ ) dan $0,320 \mathrm{~kg} / \mathrm{cm}^{2}$ (kedalaman $30-60$ 
$\mathrm{cm})$. Berdasarkan data tersebut dapat diambil kesimpulan bahwa jumlah tunas vetiver juga mempengaruhi peningkatan nilai kohesi. Nilai kohesidengan perkuatan 6 tunas vetiver $0,306 \mathrm{~kg} / \mathrm{cm}^{2}$ dan $0,304 \mathrm{~kg} / \mathrm{cm}^{2}$. Nilai tersebut lebih besar dibandingkan nilai kohesi dengan perkuatan 3 tunas vetiver yaitu $0,325 \mathrm{~kg} / \mathrm{cm}^{2}$ dan $0,320 \mathrm{~kg} / \mathrm{cm}^{2}$. Dengan range nilai kohesi $0,250 \mathrm{~kg} / \mathrm{cm}^{2}$ - 0,500 $\mathrm{kg} / \mathrm{cm}^{2}$, maka tanah dapat dikategorikan dalam konsistensi teguh (firm). Konsistensi tanah meningkat dari kategori sangat lunak (very soft) pada tanah asli, menjadi konsistensi teguh (firm) setelah dilakukan perkuatan tanaman vetiver.

Tabel 4. Hasil Pengujian Kuat Geser Langsung

\begin{tabular}{|c|c|c|c|}
\hline \multirow{2}{*}{ Kedalaman } & \multirow{2}{*}{$\begin{array}{c}\text { Waktu Tanam } \\
\text { (Minggu) }\end{array}$} & \multicolumn{2}{|c|}{ Kohesi $\left(\mathrm{kg} / \mathrm{cm}^{2}\right)$} \\
\hline & & 3 Tunas & 6 Tunas \\
\hline \multirow{6}{*}{$0-30$} & $\begin{array}{c}0 \\
\text { (Tanah Asli) }\end{array}$ & 0.025 & 0,025 \\
\hline & 4 & 0,118 & 0,147 \\
\hline & 5 & 0,127 & 0,151 \\
\hline & 6 & 0,152 & 0,169 \\
\hline & 7 & 0,164 & 0,188 \\
\hline & 16 & 0,306 & 0,325 \\
\hline \multirow{6}{*}{$30-60$} & $\begin{array}{c}0 \\
\text { (Tanah Asli) }\end{array}$ & 0,025 & 0,025 \\
\hline & 4 & 0,102 & 0,11 \\
\hline & 5 & 0,123 & 0,114 \\
\hline & 6 & 0,135 & 0,144 \\
\hline & 7 & 0,144 & 0,159 \\
\hline & 16 & 0,304 & 0,32 \\
\hline
\end{tabular}

Berdasarkan Gambar 7 dapat dilihat bahwa nilai kohesi semakin meningkat siring dengan bertambahnya umur tanam tanaman vetiver. Hal ini dikarenakan semakin lama waktu tanam vetiver maka akan menghasilkan akar yang semakin banyak. Akar tanaman vetiver berfungsi untuk mengikat butiran tanah agar lebih rapat (padat). Sehingga diperoleh nilai kohesi (kemampulekatan tanah) yang semakin besar.

Nilai kohesi antara 3 tunas dan 6 tunas tanaman vetiver. Nilai kohesi dengan perkuatan 6 tunas tanaman vetiver cendrung lebih besar dibandingkan dengan nilai kohesi pada perkuatan 3 tunas vetiver. Akan tetapi, di minggu ke 5 nilai kohesi dengan perkuatan 6 tunas vetiver di kedalaman $30-60 \mathrm{~cm}$ lebih kecil dibandingkan dengan nilai kohesi dengan perkuatan 3 tunas vetiver. Hal ini sama seperti nilai kuat tekan bebas. Oleh karena itu, dapat disimpulkan bahwa hal ini terjadi karena akar tanaman vetiver belum sampai ke posisi pengambilan sampel uji. Sehingga untuk penelitian selanjutnya perlu ditinjau kembali pengaruh posisi pengambilan sampel.

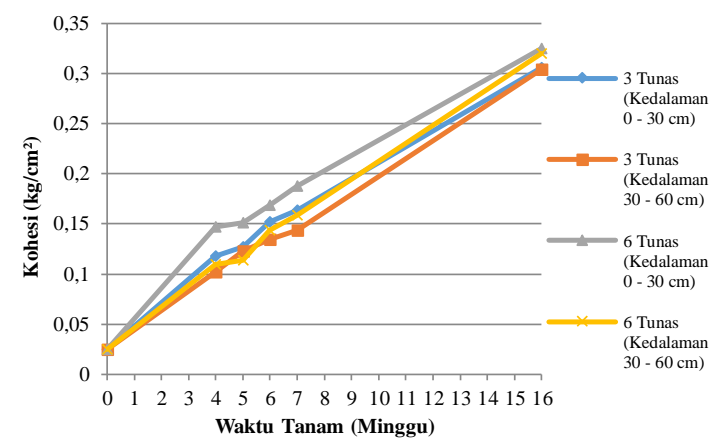

Gambar 7. Grafik Waktu Tanam vs Kohesi

\section{Analisa Stabilitas Lereng}

Analisa stabilitas lereng dilakukan dengan menggunakan bantuan program Geo Studio (Slope/W). Output dari program ini adalah nilai faktor keamanan dan bidang longsor lereng. Metode yang dipakai adalah metode bishop. Metode bishop dipilih karena dari hasil analisa dengan metode ini diperoleh nilai faktor keamanan yang paling kecil dibanding dengan metode lainnya. Nilai faktor keamanan yang kecil dapat menjadi acuan dalam menganalisa stabilitas lereng. Semakin kecil nilai faktor keamanan lereng dapat dikatakan lereng tersebut dalam kondisi tidak stabil. Kestabilan lereng dapat diketahui melalui faktor keamanan yaitu nilai faktor keamanan (FK) harus lebih besar atau dama sengan 1,30. Nilai faktor keamanan dapat diperoleh dengan mensimulasikan penampang lereng pada program Slope/W.

Lereng ditinjau pada kondisi tanah asli dan dengan perkuatan 3 dan 6 tunas vetiver. Hasil analisanya adalah sebagai berikut. 
Berdasarkan Gambar 8 dan 9 diperoleh nilai faktor keamanan lereng. Rekapitulasi nilai faktor keamanan lereng dengan perkuatan 3 dan 6 tunas tanaman vetiver Terdapat pada Tabel 5 dan Gambar 10 sebagai berikut.

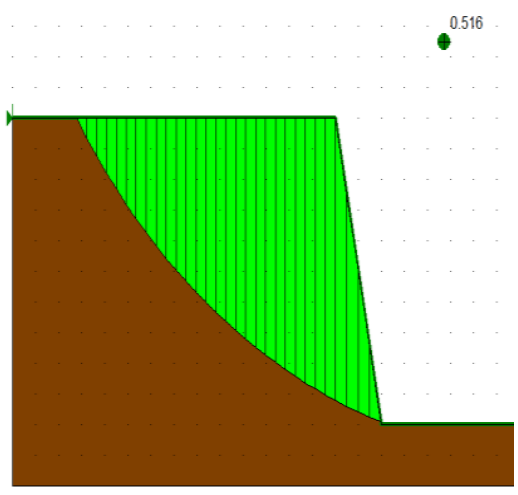

(a)

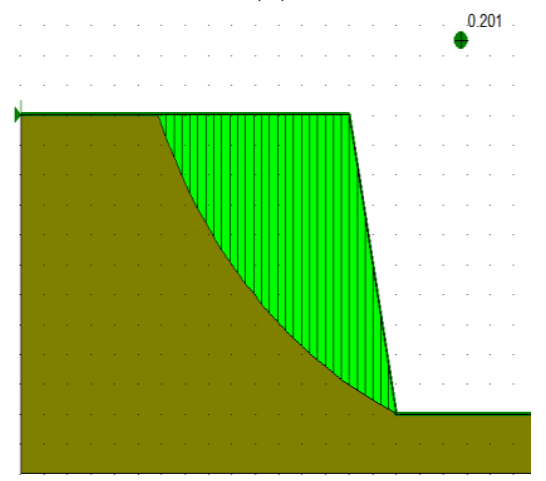

(b)

Gambar 8. Hasil Analisa Stabilitas Lereng Tanah Asli (a) Prototype 3 Tunas Vetiver (b) Prototype 3 Tunas Vetiver

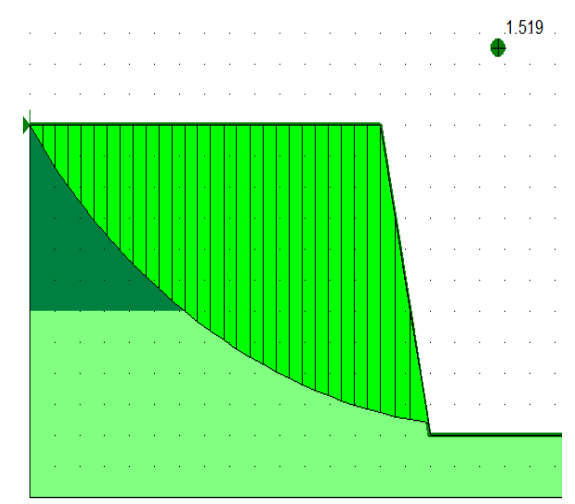

(a)

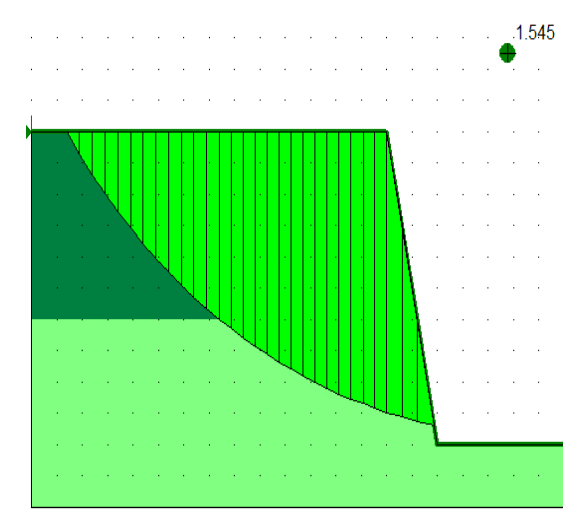

(b)

Gambar 9. Hasil Analisa Stabilitas lereng dengan Perkuatan 3 Tunas Vetiver (waktu tanam 16 minggu)

(a) Prototype 3 Tunas Vetiver

(b) Prototype Tunas Vetiver

Tabel 5. Rekapitulasi Nilai Faktor Keamanan

\begin{tabular}{|c|c|c|}
\hline \multirow{2}{*}{ Waktu Tanam } & \multicolumn{2}{|c|}{ Faktor Keamanan } \\
\hline & 3 Tunas & 6 Tunas \\
\hline 0 Minggu (Tanah Asli) & 0,516 & 0,201 \\
\hline 4 Minggu & 0,662 & 0,725 \\
\hline 5 Minggu & 0,793 & 0,817 \\
\hline 6 Minggu & 0,933 & 0,987 \\
\hline 7 Minggu & 0,964 & 1,109 \\
\hline 16 Minggu & 1,519 & 1,545 \\
\hline \multicolumn{3}{|l|}{1.8} \\
\hline \multicolumn{3}{|l|}{1.6} \\
\hline \multicolumn{3}{|l|}{$\begin{array}{l}1.4 \\
\text { 灵 } 1.2\end{array}$} \\
\hline & & \\
\hline 0.8 & & $\rightarrow-3$ Tunas \\
\hline 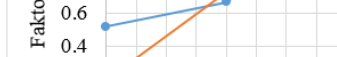 & & $\rightarrow-6$ Tunas \\
\hline 0.2 & & \\
\hline $\begin{array}{lllllllll}0 & 0 & 1 & 2 & 3 & 4 & 5 & 6 & 7 \\
& & & & & & \text { Waktu Tan }\end{array}$ & $\begin{array}{l}101112 \\
\text { (inggu) }\end{array}$ & 16 \\
\hline
\end{tabular}

Gambar 10. Grafik Nilai Faktor Keamanan

Nilai faktor keamanan tanah asli pada protoype 3 tunas dan 6 tunas akar wangi berbeda. Hal ini dikarenakan tingkat kepadatan tanah asli yang berbeda, sehingga menghasilkan nilai kuat tekan dan kohesi yang berbeda. Nilai-nilai tersebut mempengaruhi faktor keamanan lereng.

Berdasarkan Gambar 10, nilai faktor keamanan meningkat seiring dengan 
bertambahnya waktu tanam tanaman akar wangi. Hal ini terjadi karena akar tanaman akar wangi mampu mengikat butiran tanah sehingga butiran tanah menyatu satu sama lain. Semakin banyak akar tanaman akar wangi maka butiran tanah akan semakin menyatu. Dapat dilihat pada Gambar 10 nilai faktor keamanan lereng dengan perkuatan 6 tunas tanaman akar wangi lebih besar dibandingkan dengan nilai faktor keamanan lereng dengan perkuatan 3 tunas akar wangi.

Nilai kuat tekan dan kuat geser tanah dipengaruhi oleh kelekatan antar butiran tanah. Semakin besar kelekatan butiran tanah maka akan menghasilkan ketahanan yang lebih besar terhadap gaya geser maupun tekanan arah vertikal. Kemampuan tanah dalam menahan tekanan arah vertical maupun horizontal akan menghasilkan nilai faktor keamanan. Apabila nilai kuat tekan dan kuat geser tanah meningkat maka nilai faktor keamanan lereng juga akan meningkat karena ke tiga variable tersebut memiliki keterkaitan yang berbanding lurus satu sama lain.

\section{Kesimpulan}

Vetiver dapat meningkatkan kekuatan tekan maupun kuat geser tanah. Hal ini dikarenakan vetiver mampu mengikat partikel butiran tanah sehingga menghasilkan kepadatan yang cukup pada tanah untuk dapat menahan tekanan arah vertikal maupun horizontal. Peningkatan parameter tanah akan mempengaruhi stabilitas lereng. Sehingga dapat disimpulkan bahwa vetiver dapat meningkatkan stabilitas lereng. Semakin banyak jumlah tunas tanaman vetiver, akan menghasilkan nilai faktor keamanan lereng yang semakin besar.

Nilai kuat tekan dan kuat geser tanah juga dipengaruhi oleh kadar air tanah. Semakin kecil kadar air suatu tanah maka akan semakin besar nilai kohesi dan kuat tekan bebas tanah.

\section{Ucapan Terima Kasih}

Terima kasih kepada Ibu Asri Wulan yang telah memberikan ide untuk melakukan penelitian ini. Ibu Sri Wulandari yang telah membantu dalam penyusunan dan analisa data penelitian. Asisten Laboratorium Teknik Sipil Universitas Gunadarma yang telah membantu dalam proses pengujian. Serta orang tua dan teman-teman yang selalu mensuport saat penelitian berlangsung.

\section{Daftar Pustaka}

[1] L. van Du and P. Truong, "Vetiver grass system for erosion control on drainage and irrigation channels on severe acid sulfate soil in southern Vietnam," Vetiver grass Syst. Eros. Control Drain. Irrig. channels Sev. acid sulfate soil South. Vietnam, no. Photo 1, pp. 1-11, 2002.

[2] P. N. V. Truong and R. Loch, "Vetiver system for erosion and sediment control," in Proceeding of 13th International Soil Conservation Organisation Conference, 2004, no. 247, pp. 1-6.

[3] R. Wijayakusuma, "Stabilisasi Lahan Dan Fitoremediasi Dengan Vetiver System," in Green Design Seminar, 2007, no. 021, pp. 1-16.

[4] A. Noor, J. Vahlevi, and F. Rozi, "Stabilisasi Lereng untuk Pengendalian Erosi dengan Soil Bioengineering Menggunakan Akar Rumput Vetiver," Poros Tek., vol. 3, no. 2 ISSN 24427764, 2015.

[5] F. Ilham, "Karateristik Mekanis Perkuatan Lereng Menggunakan 
Geo-Root dengan Tanaman Akar Wangi Erosi permukaan lereng jalan dapat ditangani melalui berbagai metode, salah satu metode adalah dengan memanfaatkan media tanaman . Tanaman dapat berpengaruh baik untuk m," Karateristik Mek. Perkuatan Lereng Menggunakan Geo-Root dengan Tanam. Akar Wangi, pp. 1-7, 2010.

[6] Zulkarnain, "Metode Penanganan Kelongsoran Dalam Menjaga Infrastruktur Yang Ada," Anal. Numer. Pengaruh Tanam. Vetiver Terhadap Stabilitas Lereng, p. 43, 2014.

[7] D. Bina Marga, "Spesifikasi Penguatan Tebing," 1992.

[8] K. Pekerjaan Umum, "Penanaman Rumput vetiver untuk pengendalian erosi permukaan dan pencegahan longsoran dangkal pada lereng jalan," 2012. 
Putri Kurniawati dan Sri Wulandari, Analisis Pengaruh Tanaman... 